Conference Paper

\title{
From Globalisation to Glocalisation: A Study Case from Galengdowo, Jombang
}

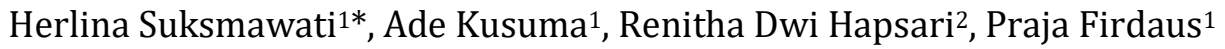 \\ ${ }^{1}$ Communication Science, Faculty of Social and Political Sciences, Universitas Pembangunan Nasional \\ "Veteran" Jawa Timur, Indonesia \\ 2International Relations, Faculty of Social and Political Sciences, Universitas Pembangunan Nasional \\ "Veteran" Jawa Timur, Indonesia
}

*Corresponding author:

E-mail: herlinasuksma@gmail.com

\begin{abstract}
This two-year study highlights the success of Bancakan Salak, a tourism event held in Galengdowo, to minimize the number of urbanization in Jombang. While modernization and globalization are all around the country-side, the threat of urbanization for rural areas is becoming significant and causes a slow-down. The event subsequently has been gradually changed the posture of Galengdowo's population. Young people are more eager to live in their village now. This cultural tourism even became very helpful in empowering the lives in Galengdowo. Bancakan Salak had attracted many locals until international tourists come. By using the quantitative method and qualitative analysis, this study has hypothetically stated that Bancakan Salak could be even more successful because of the factor of its local champions. We are also articulating the concepts of glocalization and community-based tourism. Based on the research, we found that the government of the village plays a big role in shaping the situation. The head of the village and his secretary are examples of local champions. Their role signifies one part that is very crucial in building community-based tourism (CBT) which is leadership. This strong leadership is also built under the support of persistency, broader knowledge, and working networks.
\end{abstract}

Keywords: Community-based tourism, tourism, glocalization, globalization.

\section{Introduction}

Globalization and local culture often experience contradictory relationships. The development of globalization that is manifested in the discourse of modernity almost always hurts the existence of local culture. The basic nature of globalization that is close to the ideas of universalization, westernization, and other uniform narratives has an impact on threats to local culture that arise from unique and diverse ideas from each territorial scope. This is confirmed by many cases, one of which occurred in Galengdowo Village, Wonosalam District, Jombang Regency. Galengdowo Village, like many other rural areas, experiences a phenomenon known as brain drain. Namely, the shortage of educated workers because they chose to migrate to urban areas that promised quality work and quality of life in line with the idea of modernization. Many people of productive age choose careers in urban areas by becoming office workers or factory workers. Facing the global phenomenon, this brain drain, the local government has started a big project, namely to attract back potential residents employed to build the potential of the Gelengdowo Village through tourism development that emphasizes local values. With the development of tourism, it is expected that the village economy will develop so that the welfare between urban and rural areas can be minimized. The hope is that the residents of Galengdowo Village will no longer choose careers outside the village because the village can provide employment and income stability.

\section{How to cite:}

Suksmawati, H., Kusuma, A., Hapsari, R. D., \& Firdaus, P. (2021). From globalisation to glocalisation: A study case from Galengdowo, Jombang. $5^{\text {rd }}$ International Seminar of Research Month 2020. NST Proceedings. pages 345-350. doi: 
In the previous year, research was carried out to identify tourism potential and socio-political structures in Galengdowo Hamlet with the main tourist attraction, namely the annual Bancakan Salak activity. As summarized in the final research report in the first year (2019), three conclusions can also be categorized as the potential for tourism in Bancakan Salak in Galengdowo. The first potential is the social cohesion of the Galengdowo community which is still strong. With this cohesion, not only village officials and the older generation work hand in hand in the implementation of Bancakan Salak but also the younger generation and the retired community who have left the circle of village administration. The second potential is that the Bancakan Salak which is carried out in the Galengdowo Village is a manifestation of the local noble values of the local community which reflect high gratitude, mutual giving, and togetherness. It is not surprising that Bancakan Salak can then be understood and implemented by all elements of the Galengdowo Village community. The third potential, or the last one, is the human resources in the village government that support the realization of Bancakan Salak. The most important element is the cohesiveness that occurs between the village head and the village secretary, so that this encourages the performance of villages, and also hamlets, in Galengdowo to progress rapidly.

It is not surprising that Bancakan Salak can then be implemented and implemented by all the Galengdowo Village community elements. The third potential, or the last one, is the human resources in the village government that support the realization of Bancakan Salak. The most important element is the cohesiveness that occurs between the village head and the village secretary. This encourages the performance of villages and hamlets in Galengdowo to progress rapidly.

Does this research aim to see how to implement a local value-based tourism development strategy in the Galengdowo Village area? Apart from that, what aspects need further evaluation for the development of a local value-based tourism strategy in the area, especially for attractions tourism Bancakan Salak?

\section{Material and Methods}

The 21st century has become a turning point in people's awareness of a global phenomenon commonly known as globalization. The phenomenon of globalization has become a phenomenon that is felt by all people in the world to influence fundamental aspects of their daily lives both in an individual context and within the community. In connection with the scope of globalization that includes global space, various interpretations of globalization itself emerge, for example, globalization for some people is defined as the bias of a country's territorial boundaries within the scope of information diffusion (Suryana \& Asrudin, 2009). In the study of international relations, various interpretations also arise as an explanation of the phenomenon of globalization, Martin Albrow (1990, in Smith \& Baylis, 2001) explains the phenomenon of globalization as a condition in which the world community is united into one community, namely the global community. Another view states that Globalization is what we in the Third world have for several centuries called colonization (LeGrain, 2006). More complex, Baylis and Smith (2001) explain the interpretation of globalization as a strengthening of interaction between groups of people so that events in one part of the world can have the maximum effect in other parts of the world. For academics, globalization is a global revolution and is a leap to a new reality marked by a discovery that is widely used (Hermawan, 2007). So, based on the opinions of some of the experts mentioned above, a conclusion can be drawn regarding the notion of globalization, namely, globalization is a concept of a situation in which people from various parts of the world are connected into one community in a pseudo-sense that can exchange information both in the form of real information. or contextual to reach various parts of the world and touch the fundamental aspects of human life (Scholte, 2001).

As a concrete situation, globalization also has general characteristics. According to the book Transformation in International Relations Studies by Hermawan (2007), there are four basic characteristics of the concept of globalization apart from the specific meaning of globalization, namely 
(1) Widened social relations (stretched social relations): this refers to the emergence of interconnectedness. between socio-cultural, economic, and political networks in societies that cross the boundaries of the nation-state. (2) Increased intensity of communication (intensification of flows): related to the increasing intensity of relations between actors with the emergence of developments in science and technology. (3) Increasing interpenetration: interpenetration that occurs in almost all fields results in cultures and communities residing in different areas facing each other at the local and international levels. (4) The emergence of global infrastructure (global infrastructure): institutional arrangements that are formal and informal necessary for the global network to work.

Globalist theorists believe that globalization has consequences for the integration of the world economic system with the end result of equality in the economic context (Bhagwati, 2004). The globalist argument in this context is contradicted by the skeptical argument which holds that economic integration in globalization has no positive impact on global equality. The skeptical position argues that the integration of the world economy has an impact on the concentration of capital in Europe and the United States. The relation between the diaspora phenomenon and economic globalization finds its theoretical reference to the arguments of these skeptics. That the diaspora is caused by economic inequality between countries is an argument for diaspora from an economic point of view.

Global Inequality that occurs causes economic factors to become a driving factor for skilled labor migration who feel they have the qualifications and the opportunity to get a more decent economic guarantee (Adinan, 2012). This condition causes permanent or temporary migration of the population from areas with low economies to countries with high economic security. This migration then creates problems because of the asymmetry of supply and demand (Bhagwati, 2004). This condition is based on the demand formed in developed areas only involving skilled labor, while poor areas as providers have an excess number of unskilled labor. Migration carried out by unskilled labor does not get enough area in the host area so that what happens is the phenomenon of illegal migration. This illegal migration will create new population and crime problems for the host country. Also, the problem of brain drain is exacerbated by the asymmetries of opportunity, namely the inability of poor countries to provide welfare guarantees for professional workers so that skilled labor leaves the home area and makes the development process stagnant.

In such an integrated economy, these conditions give rise to other problem consequences. Obstruction of development in one rural area will have the potential to systematically cause problems in the surrounding area. Systemically, Van (1998) argues that in the interconnection of globalization, this is a crucial global problem. Underdevelopment condition in one region will have a systemic impact in other regions and even other countries, through a massive spillover migration process. Residents who feel they have the qualifications to obtain a viable economic aspect move massively to areas deemed capable of providing this.

Garrod (2001) states that there are trends that are different from the existing tourism approaches. The first approach tends to be very legal-formal and focuses on the material benefits of having a tourism industry or tourism itself. Meanwhile, the second approach tends to be more participatory by relying on local communities to participate in tourism development in their region. The tourism industry is then really driven by the local community where the tourism destination originates. This second approach is later known as CBT (Community Based Tourism). According to Nurhidayati (2015), the definition of CBT can be divided into three basic postulates. A first postulate is a form of tourism and tourism that provides opportunities and roles for local communities to control and be involved in the management of their tourism development and development. The second postulate, namely CBT is also a tourism approach that provides parties not directly involved in tourism with an economic spill-over built from tourist destinations. Mean- 
while, the third postulate is that CBT also demands political empowerment and the democratization of benefits to communities or strata of society who are socially and economically disadvantaged.

According to Khondker (2005), "glocalization" is another version of the concept of "globalization". A version in a different direction from globalization. Khondker argues that glocalization also has a historical affiliation with the Japanese concept, "dochakuka", which is closely related to Japanese agrotechnical. Roland Robertson is an academic who popularized glocalization in the West. Robertson also has an interest in Japanese entities that have succeeded in absorbing globalization but are still very strong in upholding their locality. In a cultural context, Jan Nederveen Pieterse is one of the academics who has an understanding of glocalization, but with the concept of "mélange", or "hybridity", and syncretism.

Meanwhile, glocalization is a concept that is still being formulated for its solidity and validity as a framework of thought. As explained by Roudometof (2016), glocalization is a theoretical concept that is still ambiguous. Therefore, glocalization is still in the stage of building a solid foundation. In the development process, one of the proponents of glocalization, Roland Robertson, argues that the term "glocal" has replaced "global" and "local" at the same time. Glocalization is then claimed to have made globalization irrelevant because Robertson believes that now nothing is truly local and nothing is truly global (Gobo, 2016).

\section{Results and Discussion}

Globalization creates opportunities and challenges. While in some areas, globalization has caused a brain drain phenomenon and weakened local and cultural identity. The local government of Galengdowo, Galengdowo Village applied local-culture-based tourism as a response to the challenges of globalization. The Local government of Galengdowo, Galengdowo Village has succeeded in turning challenges into opportunity, turning the brain drain phenomenon into brain gain, and at the same time successfully using the local potential to promote tourism and maintain local identity in the era of globalization.

In its development, the efforts that have been implemented by the local government experience some obstacles. Based on the research conducted by the team's findings from field trips, it was found that two obstacles influence the dynamics conditions in this second-year study. The first dynamic is the COVID-19 pandemic. Galengdowo Village, more specifically, Galengdowo, is a white zone, which means that there is no infection or spread of COVID-19 at all in Galengdowo Village. However, this pandemic has affected the local tourism in Galengdowo Village. Because of COVID-19, the number of tourist visits to the Wonosalam area has dropped dramatically, and the regional tourism sector has been hit hard. Fewer tourists are coming from the city to stop by to buy salak or visit other destinations, so the number of sales in Galengdowo has also decreased.

The policy implemented by the central government also influences this decision. Following the increasing number of positive cases in 34 provinces in Indonesia, the central government took a policy to implement large-scale social restrictions. In its application, this policy is implemented utilizing social distancing and prohibiting all activities that gather large crowds, thereby could increasing the risk of covid-19 transmission.

This has made the village government determined to eliminate the Bancakan Salak festival. Apart from the drastic decline, of course, the village government will not give the area and population risk of infection. Because if the Bancakan Salak festival is held, then the crowd will occur in Galengdowo Village, and of course, this must be avoided during a pandemic. When it was first held in 2016, Bancakan Salak was attended by thousands of local tourists who were interested in the local traditions. Promotions carried out by the local government also succeed to increase the number of local tourists every year. This is inseparable from the efforts made by the local government, in collaborating with several national TV Stations, such as TV One, RCTI, and Net TV.

The second dynamic is the vacant political-administrative position in the neighboring village. The vacancy of this position had an indirect impact on Galengdowo Village, namely the Secretary 
of Galengdowo Village appointment, Mr. Arnowo, as Acting Daily Task Force (Plt) of the village until the political-administrative vacancies were filled. This puts more burdens on the Head of Galengdowo Village, Mr. Wartomo because he has to move village operations with more energy and thoughts. As the results of research in the first year, the leadership brought by the Village Head, Wartomo, and the Village Secretary, Arnowo, greatly influenced the performance of the Galengdowo Village government. The two local champions managed to divide their tasks well so that they could lift the performance of Galengdowo Village. In addition to the COVID-19 pandemic, the decline in the performance of Galengdowo Village was also influenced by the excessive operational burden borne by the Village Head. These two factors were obtained from the research team when doing field dives for data mining activities (in-depth interviews) with the Head of Galengdowo Village, Mr. Wartomo.

Based on the model that was compiled in the first year of this research, there is one component that hinders village tourism performance, especially for the Bancakan Salak festival, namely the institutional infrastructure component. As previously explained, at this time, there is an extra burden being carried out by the Village Head because the Village Secretary is appointed to carry out daily tasks in another village. However, according to the research team, this is not a major obstacle and needs to be addressed immediately because it will hinder the overall tourism strategy. Even though there is a slowdown, in the political-administrative context, it will gradually improve. Each village will immediately elect a new Village Head so that the Secretary of Galengdowo Village will soon be able to work together to rebuild Galengdowo Village.

Of course, the improvement in conditions in Galengdowo must be accompanied by the improvement in the community's conditions during the pandemic. Because after all, if Galengdowo continues to show performance improvement, this will be in vain because the demand and purchasing power of the public, in general, is still decreasing. Therefore, apart from the COVID-19 pandemic force majeure, it is a positive thing, according to the research team, that there are no significant obstacles in implementing the tourism strategy in Galengdowo Village, especially at the Bancakan Salak festival.

Even though these two obstacles occur, it does not hinder the efforts taken by Pokdarwis and the local government, to continue to carry out tourism targeting the local community around Galengdowo. As previously explained, there is no case or zero cases of covid-19 in Galengdowo, so it remains safe when tourism is still open to local or internal communities. The head chief of local government, Mr. Wartomo stated that educational tour "petik salak" could still be held for primary school children nearby. They were taught how to plant and harvest Salak. This effort is also used as a way to increase the children's sense of belonging towards Salak as Galengdowo's identity that must be preserved.

Also, the efforts to diversify the economy are carried out by the Small and Medium Enterprises and the local government of Galengdowo, to keep their economy running. Apart from Bancakan Salak, Salak is also produced into various kinds of processed food, such as Salak chips, Dodol Salak, Jenang Salak, and Salak syrup. These products are then marketed in several markets and events or exhibitions held by Provincial Government to promote SMEs products.

On the other hand, the government has also started to develop cow's milk production as an alternative to increase the regional income and support the local economy. This proves that the government and local communities can adapt to the dynamics of the environment. Through these efforts, communities and local governments can survive globalization and pandemics.

\section{Conclusion and Recommendation}

Based on the data mining (observation and in-depth interviews) conducted by the research team, we found that two main obstacles caused the implementation of the tourism strategy in Galengdowo Village to be hampered. The first obstacle is the existence of the COVID-19 pandemic, which affects the entire life system in Galengdowo Village. The second obstacle is the po- 
litical-administrative vacancy of the Village Secretary of Galengdowo because the Village Secretary is appointed to carry out daily tasks in another village. This directly puts more burdens on the Village Head of Galengdowo so that a decrease in performance is a natural thing. However, the research team considered that these two obstacles were not significant to overcome over time.

The advice given regarding the current condition is that strengthening human resources is the main and most important task in implementing the tourism strategy in Galengdowo Village. Leadership and leader regeneration must proceed as it should. The research team's main concern was that when regeneration did not occur, the village would continue to depend on the local champions who now have political-administrative positions in the village government, including the village head and village secretary. This is more or less reflected in the current condition of Galengdowo Village when the Secretary of Galengdowo Village had to carry out assignments in other villages.

Also, in the era of globalization, local governments can consider taking advantage of the use of developments in science and technology to start implementing digital tourism development strategies. The local government could consider starting a digitalization tourism program to promote tourism in Galengdowo, Galengdowo Village, not only nationally but also internationally. Thus, the local government and society can still maintain the brain gain as well as local identity in the era of globalization. In this case, the ability to adapt to the development and the dynamics in the environment is also very important.

\section{Acknowledgment}

A big thank you to LPPM UPN "Veteran" East Java who has fully funded this research through the Skim Riski Mandiri Fund, all agencies and individuals who have provided moral and material support during the implementation of research activities.

\section{References}

Adinan, J. (2012). Brain drain of Health Professionals in Tanzania. New York: Cornell University.

Bhagwati, J. (2004). In Defense of Globalization. Oxford: Oxford University Press.

Garrod, B. (2001). Local participation in the planning and management of ecotourism: A revised model approach. Research Report. Bristol: University of the West of England.

Gobo, G. (2016). Glocalization: A Critical Introduction. European Journal of Cultural and Political Sociology. DoI: http://www.tandfonline.com/action/showCitFormats?doi=10.1080/23254823.2016.1209886.

Hermawan, Y. (2007). Transformasi dalam studi hubungan internasional. Yogyakarta: Graha Ilmu.

Khondker, H. (2005). Globalisation to glocalisation: A conceptual exploration. Intellectual Discourse, 13(2), 1-10.

LeGrain, P. (2006). Brain drain or Brain Gain? The Cost and Benefits of SkilledEmigration. in Immigrants: Your Country Needs Them. London: Little Brown.

Nurhidayati, S, E. (2015). Studi evaluasi penerapan community based tourism (CBT) sebagai pendukung agrowisata berkelanjutan. in Masyarakat, Kebudayaan, dan Politik, 28(1), 1-10.

Roudometor, V. (2016). Glocalization a critical introduction. Routledge: London and New York.

Scholte, J, A. (2001). The globalization of world politics," in Baylis, John \& Smith, Steve (eds.), The Globalization of World Politics, 2nd edition, Oxford University Press, pp. 13-34.

Smith, S., Baylis, J. (2001). Introduction," in Baylis, John \& Smith, Steve (eds.), The Globalization of World Politics, 2nd edition, Oxford University Press, pp. 1-12.

Suryana, Asrudin, M. J. (2009). Refleksi teori hubungan internasional (dari Tradisional ke Kontemporer). Graha Ilmu.

Van, H., N. (1998). Migrants and hosts, transnationals and stayers", in New diasporas: The Mass Exodus, Dispersal and Regrouping of Migrant Communities. University of Washington Press. 